\title{
Paradoxes of Poweshiek Skipperling (Oarisma poweshiek) (Lepidoptera: Hesperiidae): Abundance Patterns and Management of a Highly Imperiled Prairie Species
}

\author{
Ann B. Swengel and Scott R. Swengel \\ 909 Birch Street, Baraboo, WI 53913, USA \\ Correspondence should be addressed to Ann B. Swengel; swengel@naba.org
}

Received 29 October 2013; Accepted 20 November 2013; Published 19 January 2014

Academic Editors: C. Cordero and O. Nedvěd

Copyright (C) 2014 A. B. Swengel and S. R. Swengel. This is an open access article distributed under the Creative Commons Attribution License, which permits unrestricted use, distribution, and reproduction in any medium, provided the original work is properly cited.

\begin{abstract}
Although Oarisma poweshiek sometimes occurred in localized abundance, its known range is centered on the highly decimated northern tallgrass prairie of North America. To aid its conservation, we analyze surveys from 1988 to 1997 of populations no longer being found. While we recorded 2403 individuals at 20 sites, five sites had $87 \%$ of individuals, while 12 sites had only $2 \%$ of individuals. Most surveys during $O$. poweshiek flight had zero individuals recorded. In peak vegetative characteristics for $O$. poweshiek, fire management had the highest mean abundance but the lowest median abundance and lowest percent occurrence compared to idling and haying. Mean abundance was by far the lowest in the first year postfire compared to longer since fire. Median abundance and percent unit surveys where O. poweshiek was found indicated higher abundances the longer since fire. Although this skipper occasionally exhibited super-recoveries after fire, the median result in fire-managed occupied sites was zero. In a few years, abundance appeared synchronized across many sites, either low $(1993,1997)$ or high $(1994-1995)$. It is only through a constant focus on avoiding the worst-case scenario that the rare best-case scenario of long-term population persistence appears possible for O. poweshiek.
\end{abstract}

\section{Introduction}

Oarisma poweshiek (Poweshiek skipperling) (Lepidoptera: Hesperiidae) is specialized to native herbaceous flora, with a relatively small range centered on northern tallgrass prairie in North America from eastern Wisconsin to Iowa, Minnesota, the eastern Dakotas, and southeastern Manitoba, as well as populations in fen wetlands in the lower peninsula of Michigan [1-6]. Reported caterpillar food plants include dominant but finer threadlike grasses of tallgrass prairie such as Sporobolus heterolepis (prairie dropseed), Schizachyrium scoparium (little bluestem), Bouteloua curtipendula (sideoats grama), and the coarser Sorghastrum nutans (Indian grass), as well as Carex (sedges) and Eleocharis elliptica (spike-rush) primarily for the Michigan populations [6-11]. However, little research is available to confirm larval host plants in the field in much of its range.
Since European contact in North America, tallgrass prairie has been about $99 \%$ destroyed in most central North American states and provinces, primarily for conversion to agriculture, with never-tilled prairie fragments remaining in preserves, parks, and unintensively utilized farmland $[12,13]$. As a result, this skipper has been of conservation concern for decades as evidenced by [11, 14-20] with decades of unpublished research reports in [6, 21]. Tremendous $O$. poweshiek decline has been documented in the last decade, not just in the unconserved landscape but also in preserves, including large ones decades after preservation $[6,10,20-23]$. Because of this, conservation effort has increased [20, 24], but further research on the species' requirements is hampered by the few populations known still to exist.

We conducted butterfly transect surveys in O. poweshiek sites in northern Iowa, western Minnesota, and eastern North Dakota during 1988-1997 as part of broader prairie 
butterfly study $[15,17,25,26]$. This study area encompassed core $O$. poweshiek range, with the largest known populations [6], but this species has since become unfindable here in recent surveys [20,21,24]. In this paper, we expand our prior summary analyses to provide more details on $O$. poweshiek patterns of population incidence and abundance and land management associations.

We also use the dataset of our and others' butterfly surveys, originally assembled for trend analyses in $[19,23]$, to portray variation in $O$. poweshiek abundance in time series at preserves in Iowa and Minnesota. Schlicht et al. [19] reported that during 1993-1996, two teams (Schlicht and Swengels) happened to survey the same Minnesota prairies in the same seasonal timing in the same years, but without any coordination of sites, routes, and dates between teams. Strong covariance occurred in abundance indices for individual butterfly species, including $O$. poweshiek, between the two teams. The validation test in Swengel et al. [23] was weaker between Saunders' and Swengels' surveys in Iowa during 1993-1994 because of less overlap in site and date. However, these comparisons also indicated a positive relationship between teams' datasets. These analyses validate assembling multiple survey datasets together to examine patterns of population abundance by site. The benefit of the multiteam dataset is more coverage of more sites over more years. However, because of differences among teams in survey methods, we did not analyze vegetative factors within sites in this dataset.

In this paper, we have two goals: (1) to describe O. poweshiek populations as an aid to its conservation and (2) to search for insights on how to improve assessments of butterflies at risk of extinction so that conservation intervention can be implemented more effectively.

\section{Materials and Methods}

2.1. Swengels' Surveys. The study sites [17] were deliberately selected for their conservation interest; that is, they were known or predicted to support prairie-specialized butterflies. Most sites were reserves in private or government ownership because of their accessibility without trespassing and importance for conservation. They ranged from 2 to 2024 ha in prairie patch size (mean 250 ha and median $97 \mathrm{ha})$. Management by cool-season burning, typically in a rotation of 2-5 years, occurred at 28 sites. Three sites and the unburned part of a fourth site were hayed (mowed, with subsequent removal of clippings) in late summer or early fall no more often than once per year, sometimes in a rotation over two years (either part hayed per year, or all hayed one year and none hayed the next). Haying and burning both occurred throughout one site. The unburned parts of four sites were idle (i.e., no active management occurred or was evident during the study). Eight areas in Sheyenne National Grassland (North Dakota) were considered separate sites because they were noncontiguous (due to intervening nonpublic nonprairie vegetation) and scattered over an area $53 \mathrm{~km}$ north-south by $42 \mathrm{~km}$ east-west. These eight areas had rotational range grazing for both ecological and economic purposes, at a stocking rate of 0.3-0.6 animal use months/ ha/yr (AUM $=500 \mathrm{~kg}$ of cattle for 1 month) with grazing from mid-May to early November $[27,28]$. One of these sampled areas was also burned. Prairie patch sizes were grouped into three classes, small (13-20 ha), intermediate ( $>30$ and $<130 \mathrm{ha}$ ), and large (>140 ha), with 6,17 , and 17 sites, respectively.

We conducted transect butterfly surveys between 20 June and 21 August 1988-1997 along similar routes each year [15, $17,25,26]$. Walking at a slow pace $(1.5-2 \mathrm{~km} / \mathrm{hr})$ on parallel routes 5-10 m apart, we counted all adult butterflies observed ahead and to the sides, to the limit of species identification (possibly with binoculars after detection) and our ability to track individuals. Within a site, a new sampling unit (i.e., subsite) was designated whenever the habitat along the route changed markedly by vegetation type (wetland, wet/wetmesic, mesic, dry-mesic/dry, "extra dry" sand), management (type and/or years since last treatment), and/or vegetative quality (degraded, semi-degraded, undegraded) based on amount of brush and diversity and abundance of native and nonnative flora. Routes crossed rather than followed ecotones and management boundaries to reduce edge effects. Most formal surveys occurred during 1990-1997, with a few also in 1988-1989. All sites could not be visited each year but most were visited more than once both within a year (2-5 weeks apart) and among years. Survey timings were selected especially to sample prairie-specialist butterflies, as classified in Swengel $[15,25]$, including O. poweshiek. Surveys occurred during a wide range of weather conditions and times of day. Occasionally, surveys occurred in intermittent light drizzle, so long as butterfly activity was apparent, but not in continuous rain.

For each unit, we recorded temperature, time and distance spent surveying, wind speed, percent cloud cover, and percent time the sun was shining. Management year-class (years since last treatment) was coded as 0 years $(<1$ year) since last treatment, 1 ( $\geq 1$ but $<2$ years ago), 2 , and so forth. A fire year-class ("year-burn") of 0 signifies the unit was burned in the cool season (fall or spring, usually the latter) since the last growing season. For example a fire after summer 1987 and before summer 1988 is said here to have burned in 1988 (before the growing season). For units with more than one management type, management year-class was tracked separately for each management. Site selection, vegetative type and quality, prairie size, and management treatments during the study period were based on Iowa State Preserves Board [29], Wendt [30], The Nature Conservancy Minnesota Chapter [31, 32], Minnesota Department of Natural Resources [33], and brochures and personal communications from the managing agencies. A unit occurred in a topographically "diverse" site if it contained contiguous unforested and uncultivated vegetation both wetter and drier than mesic; otherwise the site was coded "uniform."

2.2. Other Datasets. Schlicht et al. [19] and Swengel et al. [23] assembled datasets of prairie butterfly surveys. Coverage of functioning $O$. poweshiek populations is available 
for Minnesota in 1988-1990 [34, 35] and 1993-1997 [3639], and for Iowa in 1993-1994 [40]. We also include in this dataset our informal observations during 1988-1989 in this study region where we quantified butterfly observations by date and site and approximate effort (time only) but not survey conditions or unit characteristics. From these datasets and our formal surveys, we assembled time series of O. poweshiek abundance per site per year for as many years as possible.

2.3. Analyses. We computed all statistics with ABstat 7.20 software (Parker, CO, USA). In Swengel survey dataset, we calculated observation rates (relative densities or abundances) as individuals observed per $\mathrm{km}$ in each unit survey. It was necessary to standardize the data as observation rates because the routes varied in length among units. Unit surveys were included in an analysis only if held on dates during $O$. poweshiek observed flight period (i.e., within the span of dates we observed adults that year) at sites where the species was ever recorded during the formal surveys. Analysis was performed at the scale of the unit rather than by site, because unit surveys within the same site varied, sometimes considerably, in vegetative characteristics. Statistical significance was set at $P<0.05$. Since significant results occurred at a frequency well above that expected due to spurious Type I statistical error, the critical $P$ value was not lowered further, as more Type II errors (biologically meaningful patterns lacking statistical significance) would be created than Type I errors eliminated. We use the Chi Square goodness of fit test to examine skewing compared to distribution proportional to survey effort, and the Mann-Whitney $U$ test to test for significant differences in observation rates on unit surveys among management types.

We used the analyses in A. B. Swengel and S. R. Swengel [17] to identify vegetative factors to control in more detailed analysis of site management. In that prior summary analysis, O. poweshiek observation rates significantly peaked in units that were undegraded, upland (dry-mesic or dry prairie, but not harshly dry sand prairie), and in topographically diverse sites (i.e., containing both wetter and drier than mesic grassland). Wet/wet-mesic and mesic units had statistically similar lower observation rates, as did sites with relatively uniform topography (sites with all wetter than mesic prairie; in both our formal and informal observations, we found no O. poweshiek in sites that were uniformly drier than mesic). Low numbers occurred in wetland (sedge meadow) but the sample for that vegetation type was too small to test statistically. Our analysis did not detect a distinction between large sites (mean $8.41 / \mathrm{km}$ ) and intermediate ones (mean $11.25 / \mathrm{km}$ ). Observation rates were much lower in small sites $(1.18 / \mathrm{km})$ but this sample was small and not significant. The median $O$. poweshiek observation rate for each code of these analyzed factors was zero, even for the code in each factor with the significantly highest abundance and even though this analysis was limited to the observed flight period only at sites where we recorded any O. poweshiek on our formal surveys. In conclusion, "peak vegetation” for this species appeared to be undegraded, upland units in diverse nonsmall sites, with a "secondary vegetation" defined as undegraded wet to mesic prairie in nonsmall sites (either diverse or uniform sites.

For abundance time series at individual sites during this study period, we used the multi-team dataset to identify the peak survey per year at each site (standardized to survey time, which was the measure of effort available for more surveys) to represent the species' abundance at a site, if during the main flight period that year. One survey during main flight period has been adequate for producing representative indices for comparisons of relative abundance within and among sites [41, 42]. In Schlicht et al. [19], it was possible to calculate a calibration constant to adjust Swengels' surveys (unlimited width transects by two surveyors on parallel routes) to be comparable to Schlicht's fixed-width singleobserver surveys. That constant is 2.4. In other words, we divided our observation rates by 2.4 to be comparable to single-survey or fixed-width transect surveys in the multiteam dataset. However, everywhere else in this study, where we report analyses only of Swengels' survey data, we did no calibration adjustment.

\section{Results and Discussion}

3.1. Incidence. In our formal surveys, we found O. poweshiek at 20 sites of 37 surveyed during the species' flight period [17]. Of the 2403 O. poweshiek individuals we formally recorded, nearly half were from one site (Table 1). Five sites disproportionately had the most (87\%) of our O. poweshiek sample. Three other sites also had reliable observations, although fewer individuals than expected based on survey effort. The remaining 12 sites had only $2 \%$ of individuals in $36 \%$ of the survey effort. Some of these low results could be vagaries of timing and weather on our surveys, but this is not likely to be the primary explanation given the concordance between survey teams matched by site and year in the multi-team analyses $[19,23]$. Our five top sites tended to be more recently preserved, even more so tended to contain long or never-firemanaged habitat occupied by $O$. poweshiek throughout our study, and all had standing water in or next to them. Our analysis in Wisconsin of the benefit of a permanent nonfire refugium in core habitat for other prairie-specialist butterflies is consistent with this [43].

We also recorded $O$. poweshiek informally at four additional sites (two in Minnesota, two in Iowa) in 1988-1989 but not on our formal surveys in the 1990s during the species' flight period. Of those four sites and the 12 highly underrepresented sites (Table 1), we and other surveyors in the multi-team dataset both surveyed seven of these sites in the 1990s. In the multi-team dataset, survey totals ranged from 0-4 individuals at all these sites, and survey totals varied by only $0-1$ individuals among teams per site. Thus, many $O$. poweshiek sites consistently had zero or very low numbers on surveys in that period. Most notable are Bicentennial and Blazing Star, which had good numbers of O. poweshiek prior to that [8] (13 and 22 individuals on our brief informal visits in 1988) but a maximum of 1 individual per survey in the $1990 \mathrm{~s}$ when most surveys were zero. Only a relatively small number of sites had any high survey totals in this period. Thus, 
TABLE 1: Number of $O$. poweshiek individuals itemized by site, for sites where we found $>50$ individuals, with expected $O$. poweshiek based on proportion of survey effort $(\mathrm{km})$ at each site. For statistical testing, the sites are grouped into three categories (chi-square $=2800.7$ and $P<0.0001)$.

\begin{tabular}{|c|c|c|c|c|c|c|}
\hline Year preserved & Site and state & $N$ individuals & $\%$ individuals & Survey km & $\%$ effort & Expected individuals \\
\hline \multicolumn{7}{|c|}{ Top five sites } \\
\hline 1978 & ${ }^{*}$ Hole-in-the & & & & & \\
\hline 1990 & Mountain, MN & 1057 & 44.0 & 46.47 & 19.7 & 473.0 \\
\hline 1986 & Prairie Coteau, MN & 477 & 20.0 & 21.97 & 9.3 & 223.5 \\
\hline 1972 & Staffanson, MN & 354 & 15.0 & 15.61 & 6.6 & 159.0 \\
\hline Unknown & ${ }^{*}$ Prairie Marshes, MN & 146 & 6.0 & 9.98 & 4.2 & 101.0 \\
\hline \multirow[t]{2}{*}{ Unknown } & ${ }^{*}$ Hartleben, ND & 54 & 2.0 & 4.30 & 1.8 & 43.0 \\
\hline & Subtotal & 2088 & 87.0 & 98.33 & 41.6 & 999.5 \\
\hline \multicolumn{7}{|c|}{ Intermediate three sites } \\
\hline 1975 & Bluestem, MN & 113 & 5.0 & 19.32 & 8.2 & 197.0 \\
\hline 1971 & Chippewa, MN & 89 & 3.5 & 17.10 & 7.2 & 173.0 \\
\hline \multirow[t]{2}{*}{$1970 \mathrm{~s}$} & Ordway, MN & 62 & 2.5 & 16.33 & 6.9 & 166.0 \\
\hline & Subtotal & 264 & 11.0 & 52.75 & 22.3 & 536.0 \\
\hline \multicolumn{7}{|c|}{ Lowest twelve sites } \\
\hline \multirow[t]{2}{*}{ Various } & Remaining 12 sites & 51 & 2.0 & 85.37 & 36.1 & 867.5 \\
\hline & Total & 2403 & 100.0 & 236.45 & 100.0 & 2403.0 \\
\hline
\end{tabular}

${ }^{*}$ Long or never-fire managed area of occupied habitat in site throughout study period. MN: Minnesota; ND: North Dakota.

O. poweshiek decline has not been sudden but instead ongoing for decades. Many populations were becoming unreliably findable during 1988-1997 in this region.

In this study area, $O$. poweshiek has been recorded at more sites $[6,14,16,21$ : about 45 plots in the range map] than other prairie-specialist skippers such as Hesperia dacotae and H. ottoe. However, by comparison, we found Speyeria idalia (regal fritillary) (Lepidoptera: Nymphalidae), perhaps the most famous prairie-specialist butterfly and of conservation concern in much of its range [44], at 33 sites [26]. S. idalia's longer flight period made it possible for us to have more survey dates (including August visits) covering the flight period for S. idalia than for O. poweshiek. Limited only to surveys during $O$. poweshiek flight period, with some years' survey periods very early in $S$. idalia flight, we still recorded $S$. idalia at 27 sites. Thus, by comparison, O. poweshiek occurred in relatively fewer sites and has a very narrow range.

3.2. Management Types. In our entire survey dataset, as analyzed in A. B. Swengel and S. R. Swengel [17] but with more details provided in Figure 1(a), long-term idling had significantly high $O$. poweshiek abundance, as evident in all measures (percent unit surveys found, mean, and a positive median). That is, if the vegetation persists as open uncanopied prairie as in this sample, then idling appears to be a relatively favorable strategy. Haying was also significantly correlated with high $O$. poweshiek abundance and in a consistent manner (across all three measures, including a positive median). Grazing was significantly low, consistently so in all three measures (including a median of zero), but the sample was small and entirely from Sheyenne National Grassland. With its dustbowl heritage of reversion to untilled vegetative cover after failed agriculture $[27,28]$, most vegetation was degraded to some degree. While our results are representative of this site, they do not generalize to represent the range of possible types of conservation grazing. In Swengel [15], O. poweshiek was the most underrepresented species in year-burn 0 . This appeared to relate both to high mortality caused by the fire and to low dispersal tendency to recolonize burned areas. But in the summary analysis in A. B. Swengel and S. R. Swengel [17], observation rates in rotational fire management had the highest standard deviation and gave a mixed signal that placed statistically both as low and high abundance. While the mean $O$. poweshiek abundance placed fire between idling and haying in the high category, the median of zero placed fire in the low category with the type of grazing we studied, and the percent unit surveys with the species found were intermediate between high and low (Figure 1(a)). This indicates an extreme range of variation in $O$. poweshiek abundance in fire-managed sites, very low numbers in most cases but a few spikes of high abundance.

When we controlled for vegetative and site characteristics (Figures 1(b) and 1(c)), haying once a year or less often showed a strong peak in wet to mesic prairie (Figure 1(c)). Based on median and percent unit surveys where found, idling and haying appeared more favorable than fire in peak vegetation (Figure 1(b)), but vice versa for the mean. Statistically, in peak vegetation, $O$. poweshiek individuals were significantly overrepresented in fire management but vice versa in secondary vegetation (Figures 1(b) and 1(c)). Those chi-square analyses are weighted by $N$ individuals. In unweighted analyses using pair-wise Mann-Whitney $U$ tests at the scale of the unit survey (Table 2), abundance did not significantly differ by management type in peak vegetation but was significantly higher in hay than burn in secondary vegetation. The three measures (mean, median, and percent unit surveys where found) gave consistent results except for 


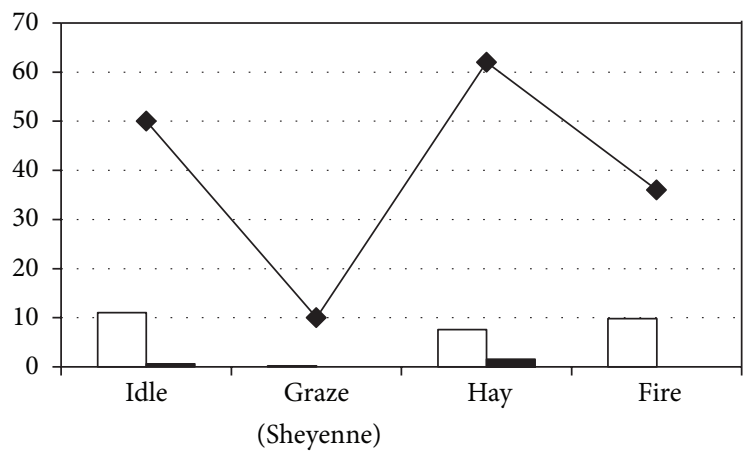

(Sheyenne)

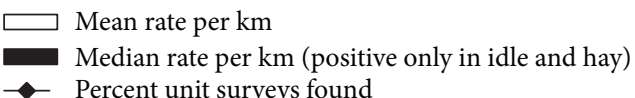

(a) All surveys

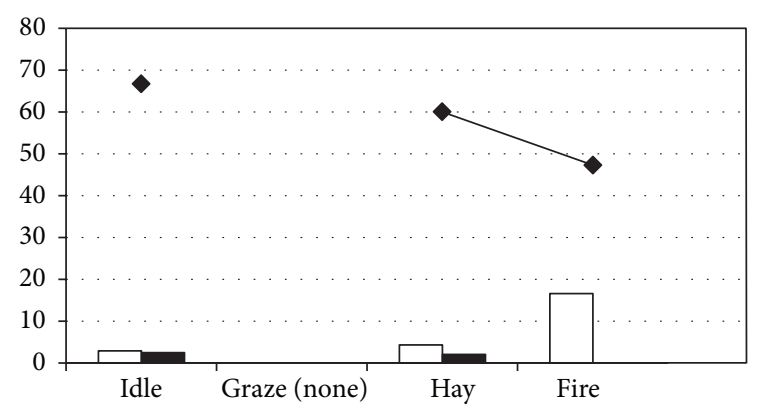

Mean rate per $\mathrm{km}$

Median rate per $\mathrm{km}$ (positive only in idle and hay)

Percent unit surveys found

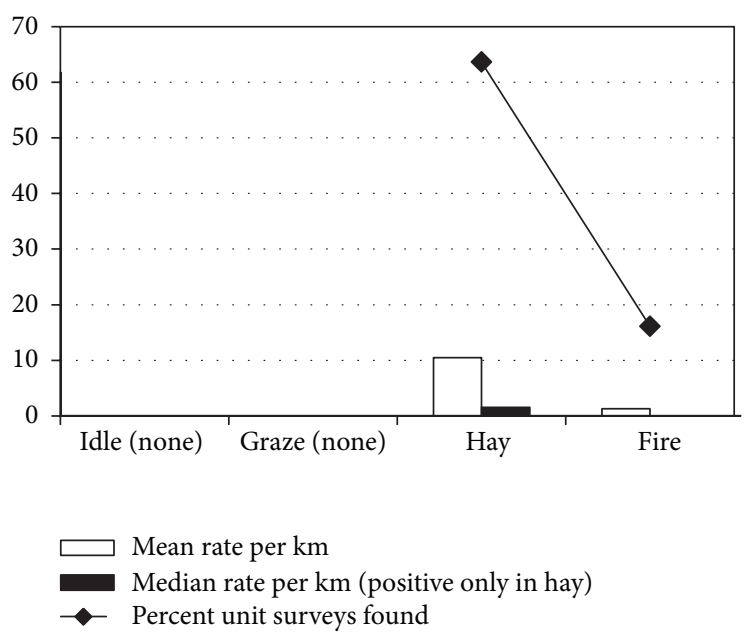

(c) Secondary vegetative type

FIGURE 1: Mean and median O. poweshiek relative abundance (individuals per km per unit survey) and percent unit surveys with the species found, by management type. For chi-square goodness of fit tests comparing $O$. poweshiek distribution among management types, expected values in each management type are calculated proportional to distance surveyed in each category. (a) in all unit surveys, as analyzed in A. B. Swengel and S. R. Swengel [17] where only the means were presented (chi-square $=45.9$ and $P<0.0001$ ), (b) In peak vegetation (chi-square $=99.3$ and $P<0.0001$ ), and $(\mathrm{c})$ in secondary vegetation (chi-square $=257.8$ and $P<0.0001$ ).

TABLE 2: Mean \pm SD, median, third quartile value (between median and maximum), and maximum value of $O$. poweshiek individuals/hr by management type. The first quartile value is zero for all samples.

\begin{tabular}{|c|c|c|c|c|c|c|}
\hline Management type & $N$ unit surveys & Mean & SD & Median & Third quartile & Maximum \\
\hline \multicolumn{7}{|c|}{ Peak vegetation } \\
\hline Idle & 6 & 2.90 & $3.42^{\mathrm{A}}$ & 2.49 & 2.80 & 9.32 \\
\hline Hay & 10 & 4.40 & $6.95^{\mathrm{A}}$ & 2.07 & 5.17 & 22.60 \\
\hline Fire & 219 & 17.09 & $36.49^{\mathrm{A}}$ & 0.00 & 12.43 & 248.56 \\
\hline \multicolumn{7}{|c|}{ Secondary vegetation } \\
\hline Hay & 11 & 10.49 & $21.14^{\mathrm{A}}$ & 1.55 & 6.21 & 70.42 \\
\hline Fire & 74 & 1.21 & $4.06^{\mathrm{B}}$ & 0.00 & 0.00 & 24.86 \\
\hline
\end{tabular}

Within each vegetative type, variates sharing the same letter are not statistically different by the Mann-Whitney $U$ test (two-tailed $P<0.05$ ). 


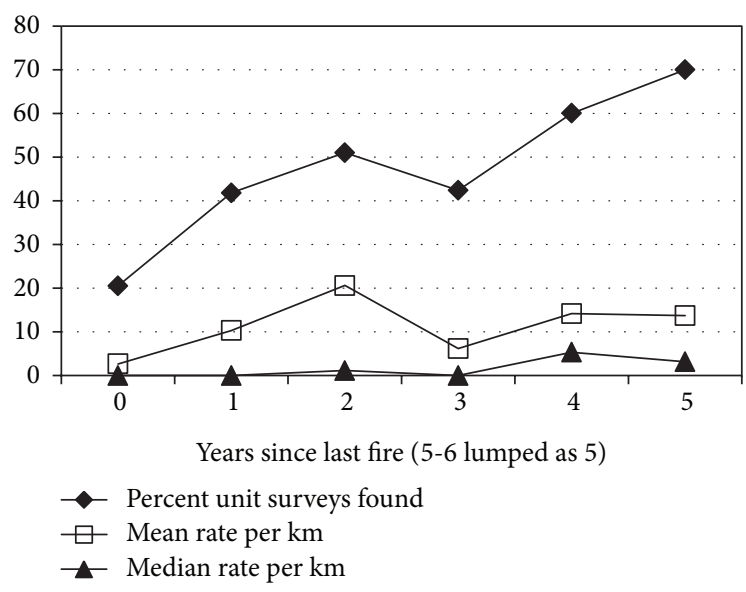

(a) All surveys

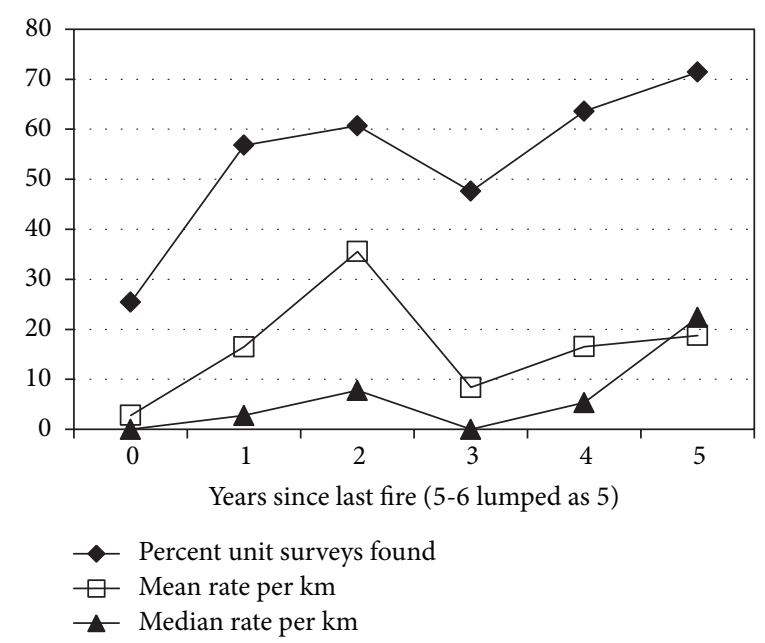

(b) Peak vegetative type

FIGURE 2: Mean and median $O$. poweshiek relative abundance (individuals per km per unit survey) and percent unit surveys with the species found, by year-burn. For chi-square goodness of fit tests comparing $O$. poweshiek distribution among different years since last fire, expected values are calculated proportional to distance surveyed in each category. (a) In all fire-managed units (chi-square $=514.9$ and $P<0.0001$ ) and (b) in peak vegetation (chi-square $=$ 576.3 and $P<0.0001)$.

fire, which continued to give a mixed signal of more extreme variation by producing the highest mean (Figure 1(b)) but the lowest median and percent unit surveys where found (Figures $1(\mathrm{~b})$ and $1(\mathrm{c})$ ).

In all surveys and in peak vegetation, when broken by fire year-class, both median $O$. poweshiek abundance and percent unit surveys where found were higher the longer since fire (Figures 2(a) and 2(b)). Mean abundance was relatively higher in year 2 than later in the fire rotation compared to median abundance. The slower recovery portrayed by the median and percent unit surveys where found is more representative of the experience in more units, and indicates that longer since fire is more favorable than more recent fire within the range of year-classes in this study. The sample was

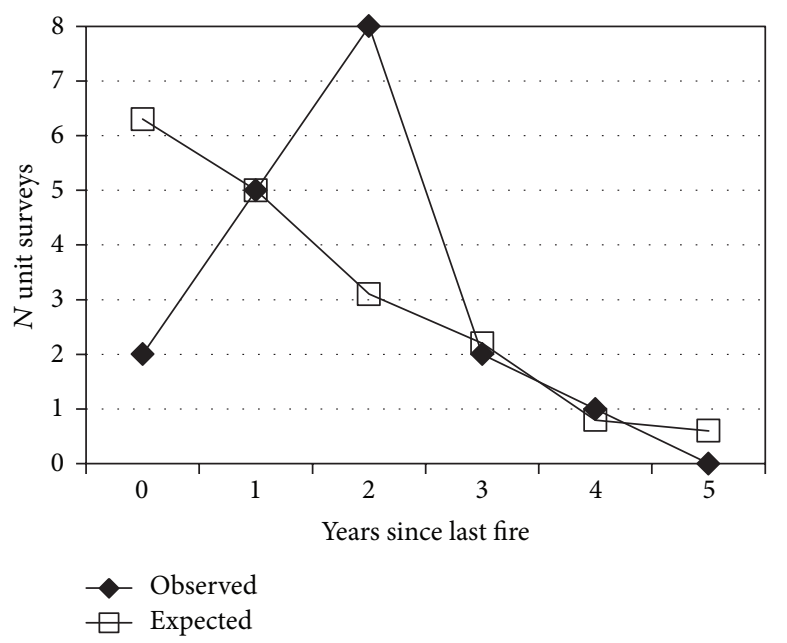

FIGURE 3: O. poweshiek distribution among fire year-classes of unit surveys exhibiting super-recovery from fire ( $\geq 50$ O. poweshiek per $\mathrm{km})$. Expected values are calculated proportional to amount of distance surveyed in each category during Poweshiek flight period at sites recording any $O$. poweshiek in this dataset. chi-square goodness of fit test, chi-square $=11.35$ and $P=0.0449$.

too small for the secondary vegetative type $(N=42$ unit surveys) to support analysis of abundance by fire year-classes. However, mean abundances in this vegetative type were similarly low in year-burn $0(1.3 / \mathrm{km})$, year-burn $1(1.5 / \mathrm{km})$, and year-burns $2-3(1.4 / \mathrm{km})$, and all medians were 0 .

We arbitrarily defined super-recovery as 50 or more $O$. poweshiek per $\mathrm{km}$ in our formal surveys, or about $21 / \mathrm{km}$ when calibrated to one-surveyor limited-width surveys as per Schlicht et al. [19]. All super-recoveries occurred in the top five sites. About $6 \%$ of unit surveys with a known fire year-class achieved that abundance (Figure 3), most often in year-burn 2 , followed by year-burn 1 . These remarkably high densities increased the mean observation rate much more than the median and percent surveys where found (Figure 2), but the latter two measures were more representative of the typical experience in fire-managed units. Percent surveys where found were highest in fire year-classes 4-6, which are the longest periods since fire in our study (Figure 2). Even in peak vegetation, combining all yearclasses, over $50 \%$ of the time we recorded zero O. poweshiek on the survey. These super-recoveries were significantly skewed, with the most overrepresentation in fire year-class 2 and most underrepresentation in fire year-class 0 (Figure 3 ). Nonetheless, two super-recoveries did occur even in yearburn 0 , a remarkable outlier from the typical extremely low $O$. poweshiek numbers in year-burn 0 (Figure 2).

$O$. poweshiek presence in units in year-burn 0 was significantly skewed toward overrepresentation in incomplete than complete combustion (Figure 4). The two super-recoveries in fire year-class 0 were in a single contiguous incomplete fire. Nonetheless, the overwhelming result in fire year-class 0 was no $O$. poweshiek found, even in incompletely combusted units, as evidenced by the percent unit surveys with $O$. poweshiek recorded (Figure 4). Furthermore, it is unclear 


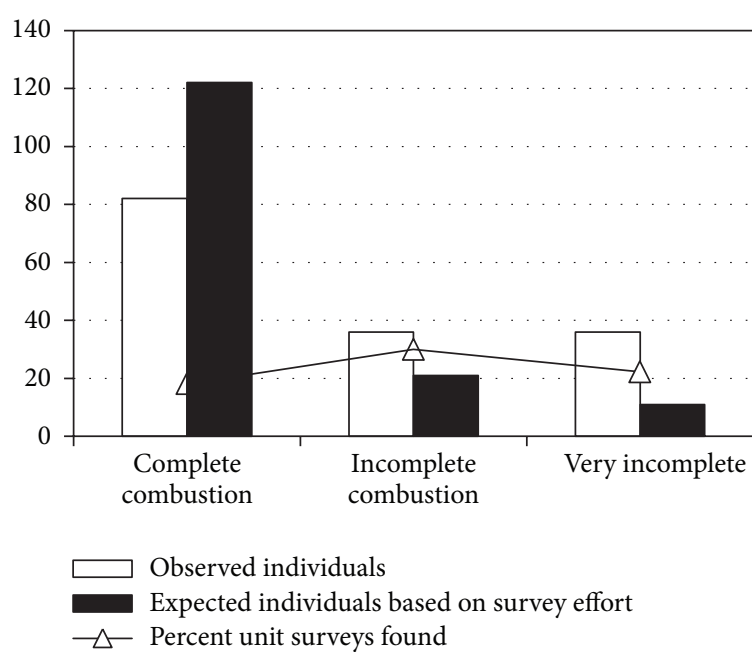

FIGURE 4: Distribution of $O$. poweshiek individuals observed in fire year-class 0 , by how completely the fire combusted dead plant litter and standing dead herbaceous cover. Expected O. poweshiek values are calculated proportional to amount of distance surveyed in each year-class. chi-square goodness of fit test $P<0.0001$ for both a three-way test and two-way test (complete versus partial and very incomplete combined), chi-square $=80.6$ and 57.7, respectively.

how much benefit partial combustion confers on $O$. poweshiek population persistence, because it is unpredictable where and how much incomplete combustion will occur. If such management accomplishes little vegetative effect, this could possibly lead to even more frequent burning. Most super-recoveries in Figure $3(N=9)$, and both superrecoveries in fire year-class 0, occurred in 1994 even though we recorded incomplete burns in $O$. poweshiek sites in four other years. This sample of super-recoveries is too small to analyze whether climatic variation among years contributed to this pattern.

As a result, rotational fire appears extremely risky for managing $O$. poweshiek sites because it is unpredictable. In a few cases, an extremely positive outcome can occur, but in most cases the outcome is a low number, usually zero, which may stay zero for years afterward, or permanently (Figures 2-4). In Manitoba, higher O. poweshiek numbers were found 6-9 years after fire than after more recent fire [45]. The rotational fire management we observed did not appear to consider the specific core areas and preferred habitats of $O$. poweshiek in a given site when determining the location and size of a particular fire. This likely contributes to the extreme range of variation in Figures 2-4: some fires occurred in areas of negligible relevance to the $O$. poweshiek population while others encompassed most or all core areas, while still burning only a portion of the site. At a minimum, these results strongly support the implementation in fire-managed sites of a permanent nonfire refugium $[23,43]$ in core $O$. poweshiek habitat, with unintensive alternative management as suggested by Figure 2 (such as rotational haying or idling combined with brush-cutting).

By contrast, rotational haying and idling (which can include localized spot treatments of brush and weeds) appeared much less risky because their medians were positive and the percent surveys where found relatively high (Figure 2). There may be fewer high spikes but the extreme bottleneck of fire year-class 0 is also avoided. These results, the numerous long-term declines in fire-managed preserves $[20,21]$, and the longer-term persistence of relatively many populations in unintensive agriculture for decades prior to conservation such that they existed to be preserved, support managing $O$. poweshiek habitat with unintensive nonfire techniques.

While idling and haying had the highest percent found (Figure 2), idling still had $50 \%$ of unit surveys with zero $O$. poweshiek recorded. From this point of view, unintensive haying compatible with maintaining the prairie flora required by $O$. poweshiek looks safest (only $38 \%$ unit surveys had zero recorded), although caution must still be exercised to avoid that $38 \%$. On the other hand, haying in this study was primarily represented by private farming, rather than how conservation managers could do it when taking $O$. poweshiek requirements and sensitivities in consideration. Thus, our surveys likely understate the benefit haying could have for $O$. poweshiek when done solely for conservation purposes. O. poweshiek has been observed to prefer both shorter and less dense vegetation within a site [2], perhaps in part because they often feed on the grass blade tips [46]. As a result, periodic haying may maintain a more favorable grassland structure than most other managements. Nonetheless, given how few extant $O$. poweshiek populations are recently known to exist $[20,21,24]$, extreme caution is advised in any management. Unfortunately, our sample is too small to examine abundance by hay year-class. Based on other prairie-specialist butterflies, it is highly advisable to do haying rotationally, treating only part of a site each year [15].

3.3. Annual Variation in Abundance. O. poweshiek exhibited large variation in abundance among years (Figure 5). In a few years, abundance appeared relatively synchronized across many sites, either very low $(1993,1997)$ or high (fewer sites in 1994-1995). This is often attributed to climatic variation among years [47, 48]. However, this synchrony is imperfect even in those very low and very high years. Management can contribute to this: mortality in fire year-class 0 reduced spatial autocorrelation in another specialist butterfly [49]. However, density-dependent population regulation could also contribute to these site-specific spikes and crashes (example in [47]). Because of these many sources of high variability, it is difficult in short-term or discontinuous time-series to distinguish a temporary low fluctuation from the beginning of a population decline. Conversely, spikes in abundance due to climatic variation confound interpretation of research on management effects. The importance of topographic diversity [17] indicates that even though wetland and lowland prairie registered relatively low $O$. poweshiek abundance, these areas are still important for the long-term persistence of thes species' populations. Catling and Lafontaine [1] also found evidence for the benefit of habitat diversity in Manitoba: most $O$. poweshiek were at the transition between mesic and drier parts of prairies, but the species also used sections that were 


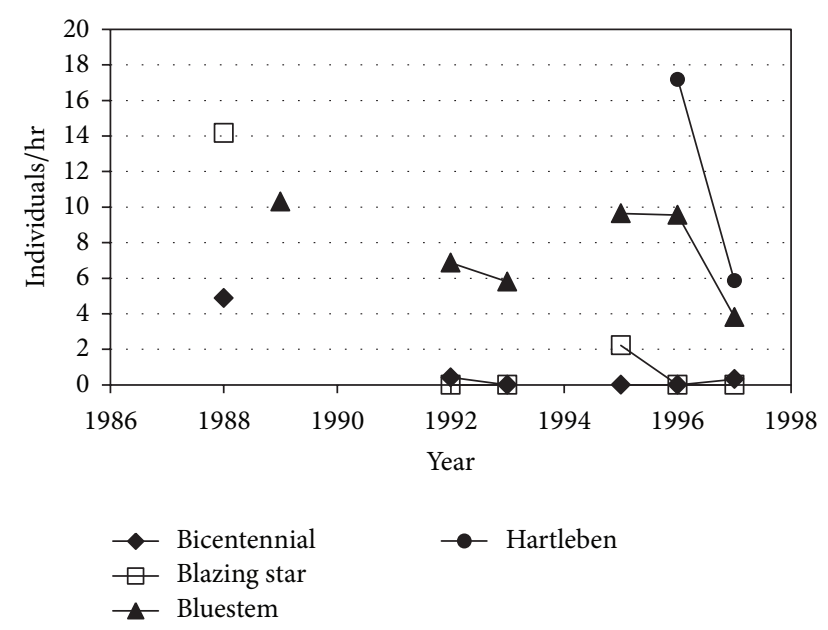

(a) Northwestern Minnesota and southeastern North Dakota

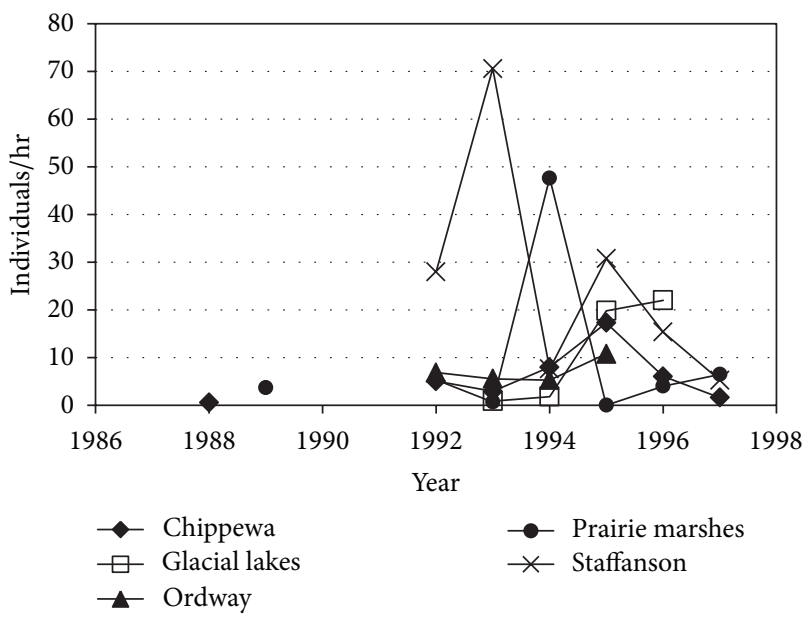

(b) West-central Minnesota

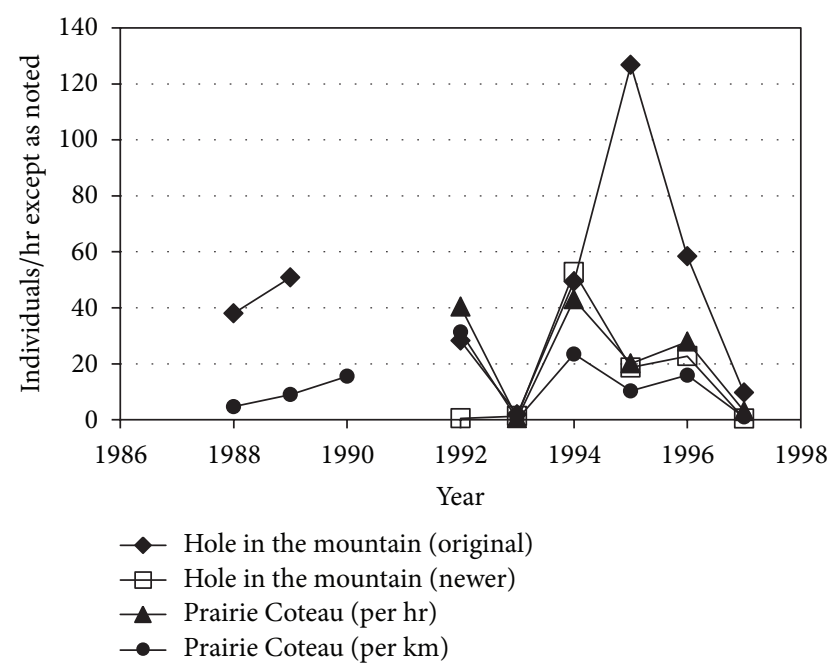

(c) Southwestern Minnesota

FIgURE 5: O. poweshiek observation rates (individuals per hr except as noted) during 1988-1997, by site: (a) in northwestern Minnesota (Clay County) and adjacent southeastern North Dakota (Hartleben in Richland County), (b) west-central Minnesota (Chippewa, Douglas, Lyon, Pope, and Swift Counties), and (c) southwestern Minnesota (Lincoln and Pipestone Counties). only wet or only dry. Since larval success is the overwhelming limiting factor in the global experience of successful rare butterfly maintenance [47], we hypothesize that topographic diversity confers benefit to O. poweshiek populations because the low places produce better larval survival in drought and high places help survival in floods. As a result, it is advisable to consider other factors that can contribute a range of climatic ameliorations, such as variation in dead plant litter depth and shade from tree lines or small groves of trees or shrubs, and deliberately maintain as wide a range of microclimatic conditions as possible in these sites.

\section{Conclusion}

O. poweshiek illustrates a frequent scenario in butterfly conservation globally $[47,50]$ : a species limited in range and site occupancy much more so than its larval host plants $[2,11,38]$, even when those habitat patches are as few and fragmented as tallgrass prairie. Great variability in $O$. poweshiek incidence and abundance among native prairie vegetative types [17] and among years (Figure 5) means that much more margin for error is required in all conservation actions because the outcome may be at the worse end of the variation instead of the better than average. Schlicht and Saunders [38] warned, after a widespread low year for prairie skippers, that such caution is especially needed when populations are at low points and are occupying only small parts of their sites. The fluctuation evident in the coming summer surveys is unknowable at the time most land management occurs (e.g., cool-season burning and fall haying). Creating and maintaining permanent nonfire refugia managed without fire is one way to hedge against this risk in fire-managed sites, as this measure significantly benefits other specialized butterflies [23, 43]. Greater variation and more frequent catastrophes (e.g., mortality from fire) are known to cause a greater risk of population extirpation than populations of the same average size that have less variability [51].

Outlier high counts in our survey experience are memorable even decades later, but the many low and zero counts are not. Even nonanecdotal data analysis is positive-biased. Means are skewed high by the few outlier high counts but medians are often unhelpful because they are all zero even when there are statistically significant differences among groups, as in the vegetative analyses in A. B. Swengel and S. R. Swengel [17]. Studies are biased by results in good sites and good years because that affords the most statistical power, but most populations are small and survival of the low-abundance years is a critical limiting factor that must be understood. In general the best sites are targeted for conservation first. Since fire management is skewed toward conserved sites, it is occurring in better habitat vegetatively than the other managements, which are biased negatively by being in poorer vegetative characteristics and/or by being for agricultural purposes rather than conservation applications. Surveying is often biased to "new" (newly preserved) sites to inventory the biota, where new management such as fire has an incomplete influence on the population still, while resurveys at "old" sites are a lower priority. As a result, 
declines at "old" sites are relatively poorly documented while it is happening.

The harsh limiting factors evident in all those zeroes in our O. poweshiek dataset express themselves as population losses that eventually become inescapable to notice. Unfortunately, that is well past when the most efficient, effective conservation research and intervention can occur. If O. poweshiek and similar species are to persist, these positive biases must be counteracted effectively so that conservation planning is not too optimistic in expectations about what populations of species such as $O$. poweshiek can tolerate. It is only through a constant focus on avoiding the worst-case scenario that the rare best-case scenario of long-term population persistence appears possible for extremely specialized butterfly populations like O. poweshiek.

\section{Conflict of Interests}

The authors declare that there is no conflict of interests regarding the publication of this paper.

\section{Acknowledgments}

The Swengel surveys were funded in part by the Minnesota Chapter of The Nature Conservancy (1990-1991) and Drs. William and Elsa Boyce (1992-1997). The authors are very grateful to the many lepidopterists who have surveyed prairie butterflies and shared their observations with them, and to the agencies that have supported their surveys and posted them on the Internet. They appreciate the helpful comments from two anonymous reviewers.

\section{References}

[1] P. M. Catling and J. D. Lafontaine, "First documented record of Oarisma powesheik (Lepidoptera, Hesperiidae) in Canada," Great Lakes Entomologist, vol. 19, pp. 63-66, 1986.

[2] K. S. Summerville and C. A. Clampitt, "Habitat characterization of five rare insects in Michigan (Lepidoptera: Hesperiidae, Riodinidae, Satyridae; Homoptera: Cercopidae)," Great Lakes Entomologist, vol. 32, no. 3, pp. 235-238, 1999.

[3] G. M. Marrone, Field Guide to Butterflies of South Dakota, South Dakota Department of Game, Fish and Parks, Pierre, SD, USA, 2002.

[4] R. A. Royer, Butterflies of North Dakota: An Atlas And Guide, Minot State University, Minot, ND, USA, 4th edition, 2003.

[5] E. H. Metzler, J. A. Shuey, L. A. Ferge, R. A. Henderson, and P. Z. Goldstein, "Contributions to the understanding of tallgrass prairie-dependent butterflies and moths (Lepidoptera) and their biogeography in the United States," Bulletin of the Ohio Biological Survey, vol. 15, no. 1, pp. 1-143, 2005.

[6] G. Selby, "Status assessment and conservation guidelines: poweshiek skipperling Oarisma poweshiek (Parker) (Lepidoptera: Hesperiidae) Illinois, Iowa, Michigan, Minnesota, North Dakota, South Dakota, Wisconsin," Report for the Twin Cities Field Office, U.S. Fish and Wildlife Service, Bloomington, Minn, USA, 2005, http://www.fws.gov/midwest/endangered/insects/ posk_sa.pdf.
[7] R. W. Holzman, "Eastern range extension for Oarisma poweshiek Parker (Lepidoptera, Hesperiidae)," Great Lakes Entomologist, vol. 5, pp. 111-114, 1972.

[8] T. McCabe and R. L. Post, Skippers (Hesperioidea) of North Dakota, North Dakota Insects Publication No. 11, Schafer-Post Series, Department of Entomology and Agricultural Experiment Station, North Dakota State University, Fargo, ND, USA, 1977.

[9] P. Klassen, A. R. Westwood, W. B. Preston, and W. B. McKillop, The Butterflies of Manitoba, Manitoba Museum of Man and Nature, Winnipeg, Canada, 1989.

[10] D. W. Schlicht, J. C. Downey, and J. C. Nekola, The Butterflies of Iowa, University of Iowa Press, Iowa City, Iowa, USA, 2007.

[11] D. A. Landis, A. K. Fiedler, C. A. Hamm et al., "Insect conservation in Michigan prairie fen: addressing the challenge of global change," Journal of Insect Conservation, vol. 16, no. 1, pp. 131-142, 2012.

[12] J. T. Curtis, The Vegetation of Wisconsin: An Ordination of Plant Communities, University of Wisconsin Press, Madison, Wisc, USA, 1959.

[13] F. Samson and F. Knopf, "Prairie conservation in North America," BioScience, vol. 44, pp. 418-421, 1994.

[14] B. Coffin and L. Pfannmuller, Eds., Minnesota's Endangered Flora and Fauna, University of Minnesota Press, St. Paul, Minn, USA, 1988

[15] A. B. Swengel, "Effects of fire and hay management on abundance of prairie butterflies," Biological Conservation, vol. 76, no. 1, pp. 73-85, 1996.

[16] D. W. Schlicht and T. T. Orwig, "The status of Iowa's Lepidoptera," Journal of the Iowa Academy of Science, vol. 105, no. 2, pp. 82-88, 1998.

[17] A. B. Swengel and S. R. Swengel, "Observations of prairie skippers (Oarisma poweshiek, Hesperia dacotae, H. Ottoe, $H$. leonardus pawnee, and Atrytone arogos iowa) (Lepidoptera: Hesperiidae) in Iowa, Minnesota, and North Dakota during 1988-1997," Great Lakes Entomologist, vol. 32, no. 4, pp. 267-292, 1999.

[18] Wisconsin Department of Natural Resources, The Endangered and Threatened Invertebrates of Wisconsin, Bureau of Endangered Resources, Wisconsin Department of Natural Resources, Madison, Wisc, USA, 1999.

[19] D. Schlicht, A. Swengel, and S. Swengel, "Meta-analysis of survey data to assess trends of prairie butterflies in Minnesota, USA during 1979-2005," Journal of Insect Conservation, vol. 13, no. 4, pp. 429-447, 2009.

[20] J. Dupont, Ed., Minutes from the Poweshiek Skipperling Workshop, March 24th \& 25th, Winnipeg, Manitoba, the Nature Conservancy of Canada, Manitoba Region, Winnipeg, Canada, 2011, http://www.poweshiekskipper.org/Final_POSK_Workshop_ 2011[1].pdf.

[21] G. Selby, "Status assessment update (2010), Powes hiek Skipperling Oarisma poweshiek (Parker) (Lepidoptera: Hesperiidae) Illinois, Iowa, Michigan, Minnesota, North Dakota, South Dakota, Wisconsin," Twin Cities Ecological Services Field Office, US Fish and Wildlife Service Bloomington, Minn, USA, 2010, http://www.fws.gov/midwest/endangered/insects/ posk/pdf/posk_sa_updateNov2010pdf.pd.

[22] A. B. Swengel, "Poweshiek paradise lost," American Butterflies, vol. 19, no. 4, pp. 17-33, 2008.

[23] S. R. Swengel, D. Schlicht, F. Olsen, and A. B. Swengel, "Declines of prairie butterflies in the midwestern USA," Journal of Insect Conservation, vol. 15, no. 1, pp. 327-339, 2011. 
[24] Minnesota Zoo, Saving Minnesota's Prairie Butterfly Heritage, Minnesota Zoo, Apple Valley, Minn, USA, 2003, http://www .mnzoo.org/conservation/conservation_mn_butterfly.asp.

[25] A. B. Swengel, "Effects of management on butterfly abundance in tallgrass prairie and pine barrens," Biological Conservation, vol. 83, no. 1, pp. 77-89, 1998.

[26] A. B. Swengel and S. R. Swengel, "Co-occurrence of prairie and barrens butterflies: applications to ecosystem conservation," Journal of Insect Conservation, vol. 1, no. 2, pp. 131-144, 1997.

[27] J. D. Kobriger, D. P. Vollink, M. E. McNeill, and K. F. Higgins, "Prairie chicken populations in the Sheyenne Delta, North Dakota, 1961-1987," in Prairie Chickens on the Sheyenne National Grassland, A. J. Bjugstad, Ed., pp. 1-7, General Technical Report RM-159, USDA Forest Service Rocky Mountain Forest and Range Experimental Station, Ft. Collins, Colo, USA, 1988.

[28] L. L. Manske, W. T. Barker, and M. E. Biondini, "Effects of grazing management treatment on grassland plant communities and prairie grouse habitat," in Prairie Chickens on the Sheyenne National Grassland, A. J. Bjugstad, Ed., pp. 58-72, General Technical Report RM-159, USDA Forest Service Rocky Mountain Forest and Range Experimental Station, Ft. Collins, Colo, USA, 1988.

[29] Iowa State Preserves Board, Directory of State Preserves, Iowa Department of Natural Resources, Des Moines, Iowa, USA, 1981.

[30] K. M. Wendt, A Guide to Minnesota Prairies, Minnesota Department of Natural Resources Natural Heritage Program, St. Paul, Minn, USA, 1984.

[31] The Nature Conservancy Minnesota Chapter, Minnesota Chapter Preserve Guide, The Nature Conservancy, Minneapolis, Minn, USA, 1988.

[32] The Nature Conservancy Minnesota Chapter, Minnesota Chapter Preserve Guide, The Nature Conservancy, Minneapolis, Minn, USA, 1994.

[33] Minnesota Department of Natural Resources, A Guide to Minnesota's Scientific and Natural Areas, Scientific and Natural Areas Program, St. Paul, Minn, USA, 1995.

[34] G. Selby and D. C. Glenn-Lewin, "A Systematic Inventory, Population Monitoring Program, and Ecological Study of Rare Lepidoptera at the Prairie Coteau Scientific and Natural Area (SNA), Pipestone County, Minnesota," Report to the Minnesota Department of Natural Resources, St. Paul, Minn, USA, 1989, http://files.dnr.state.mn.us/eco/nongame/projects/consgrant_ reports/1989/1989_glenn-lewin_selby.pdf.

[35] G. Selby and D. C. Glenn-Lewin, "An Ecological Study of the Plant/Butterfly Associations and their Response to Management, at the Prairie Coteau Scientific and Natural Area (SNA), Pipestone County, Minnesota," Report to the Minnesota Department of Natural Resources, St. Paul, Minn, USA, 1990, http://files.dnr.state.mn.us/eco/nongame/projects/consgrant_ reports/1990/1990_glenn-lewin_selby.pdf.

[36] D. Schlicht, "Population monitoring for prairie butterflies in Minnesota," Report to the Natural Heritage and Nongame Research Program, Minnesota Department of Natural Resources, St. Paul, Minn, USA, 1997, http://files.dnr.state.mn.us/eco/ nongame/projects/consgrant_reports/19961996_schlicht.pdf.

[37] D. Schlicht, "Surveys for the Dakota skipper in Minnesota," Report to the Natural Heritage and Nongame Research Program, Minnesota Department of Natural Resources, St. Paul, Minn, USA, 1997, http://files.dnr.state.mn.us/eco/nongame/ projects/consgrant_reports/1997/1997_schlicht.pdf.
[38] D. Schlicht and M. Saunders, "Status surveys for the Dakota skipper (Hesperia dacotae) and the poweshiek skipper (Oarisma poweshiek) in Minnesota, with Data on the Regal Fritillary (Speyeria idalia)," Report to the Nongame Wildlife Program, Minnesota Department of Natural Resources, St. Paul, Minn, USA, 1993, http://files.dnr.state.mn.us/eco/nongame/projects/ consgrant_schlicht_ saunders.pdf.

[39] D. Schlicht and M. Saunders, "Completion of status surveys for the Dakota skipper (Hesperia dacotae) and the poweshiek skipper (Oarisma poweshiek) in Minnesota," Report to the Nongame Wildlife Program, Minnesota Department of Natural Resources, St. Paul, Minn, USA, 1995, http://files.dnr.state.mn.us/eco/ nongame/projects/consgrant_reports/1993/1993_schlicht.pdf.

[40] M. Saunders, "Species status report for the Dakota skipper (Hesperia dacotae) and the poweshiek skipperling (Oarisma poweshiek) in Iowa," Unpublished Report to the Iowa Nongame Wildlife Program, Iowa Department of Natural Resources, Cedar Falls, Iowa, USA, 1995.

[41] J. A. Thomas, "A quick method for estimating butterfly numbers during surveys," Biological Conservation, vol. 27, no. 3, pp. 195211, 1983.

[42] A. B. Swengel and S. R. Swengel, "Long-term population monitoring of the Karner blue (Lepidoptera: Lycaenidae) in Wisconsin, 1990-2004," Great Lakes Entomologist, vol. 38, no. 3-4, pp. 107-134, 2005.

[43] A. B. Swengel and S. R. Swengel, "Benefit of permanent nonfire refugia for Lepidoptera conservation in fire-managed sites," Journal of Insect Conservation, vol. 11, no. 3, pp. 263-279, 2007.

[44] Xerces Society, The Xerces Society Red List of Butterflies and Moths, The Xerces Society, Portland, Ore, USA, 2013, http:// www.xerces.org/red-list-of-butterflies-and-moths.

[45] J. Dupont and R. Westwood, "Conservation and enhancement of the poweshiek skipperling in Manitoba," in Proceedings of the Minutes from the Poweshiek Skipperling Workshop, J. Dupont, Ed., p. 18, The Nature Conservancy of Canada, Winnipeg, Canada, March 2011.

[46] W. S. McAlpine, "Observations of the life history of Oarisma powesheik (Parker) 1870," Journal of Research on the Lepidoptera, vol. 11, pp. 83-93, 1973.

[47] J. A. Thomas, D. J. Simcox, and T. Hovestadt, "Evidence based conservation of butterflies," Journal of Insect Conservation, vol. 15, no. 1, pp. 241-258, 2011.

[48] E. Pollard and T. J. Yates, Monitoring Butterflies for Ecology and Conservation, Chapman \& Hall, London, UK, 1993.

[49] S. R. Swengel and A. B. Swengel, "Spatial synchrony in Wisconsin Karner blue (Lepidoptera: Lycaenidae) populations," Great Lakes Entomologist, vol. 38, no. 3-4, pp. 135-154, 2005.

[50] J. A. Thomas, "The conservation of butterflies in temperate countries: past efforts and lessons for the future," in The Biology of Butterflies, R. I. Vane-Wright and P. R. Ackery, Eds., pp. 333353, Princeton University Press, Princeton, NJ, USA, 1984.

[51] R. Lacy, T. Foose, J. Ballou, and J. Eldridge, "Small population biology and population and habitat viability assessment," in Section 6: Karner Blue Butterfly Population Habitat \& Viability Analysis Workshop Briefing Book, pp. 333-353, The Wilds and IUCN/SSC Captive Breeding Specialist Group, Apple Valley, Minn, USA, 1992. 

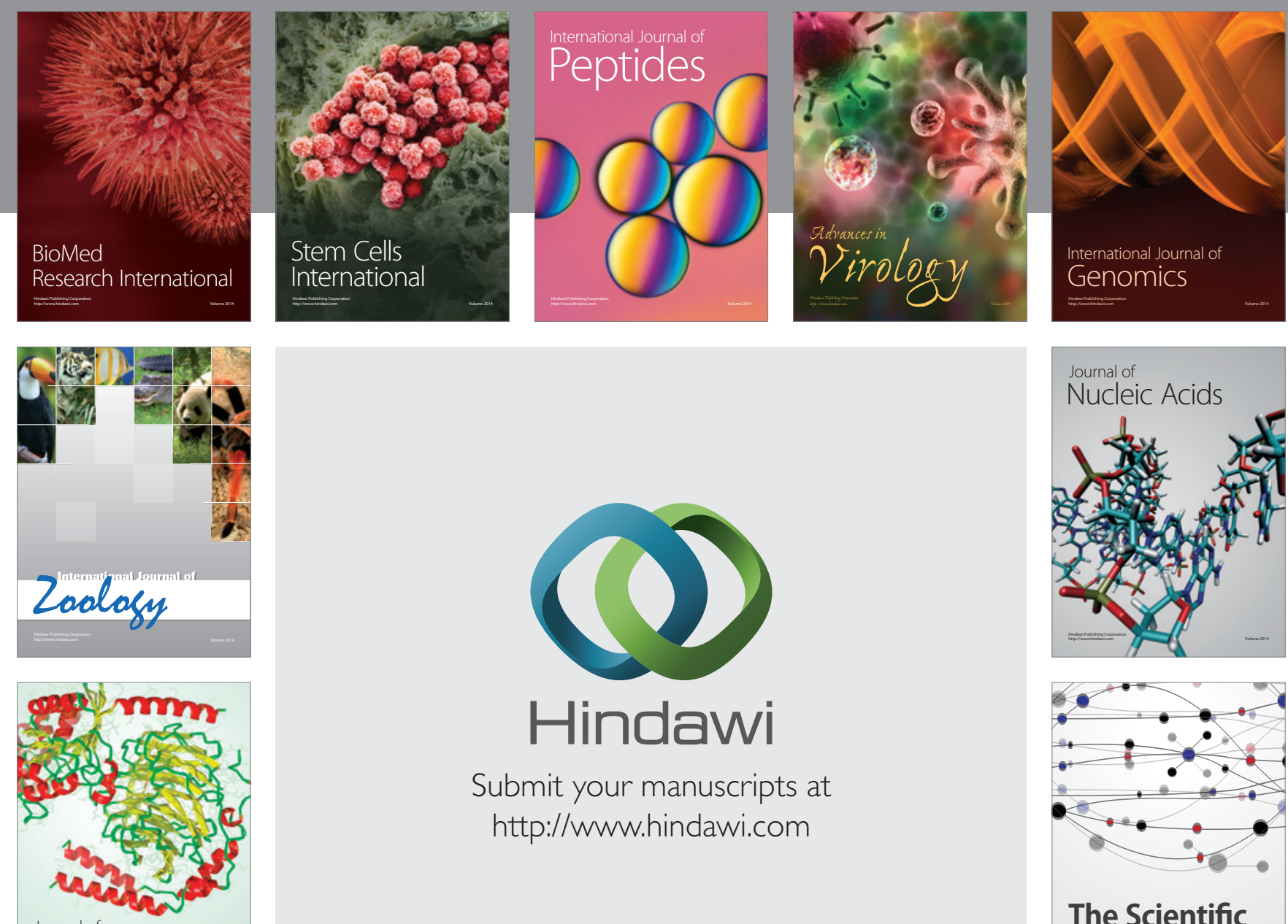

Submit your manuscripts at

http://www.hindawi.com

Journal of
Signal Transduction
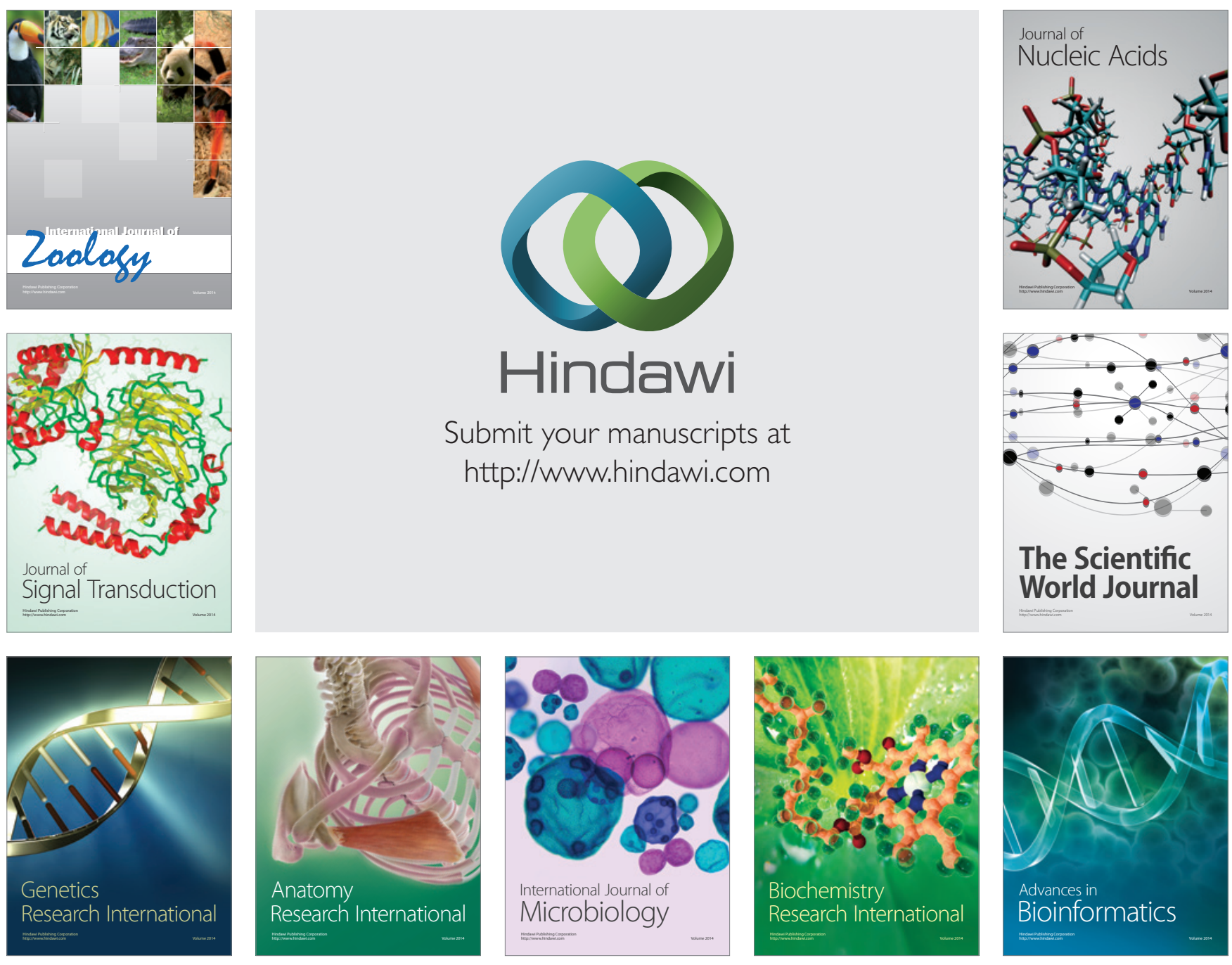

The Scientific World Journal
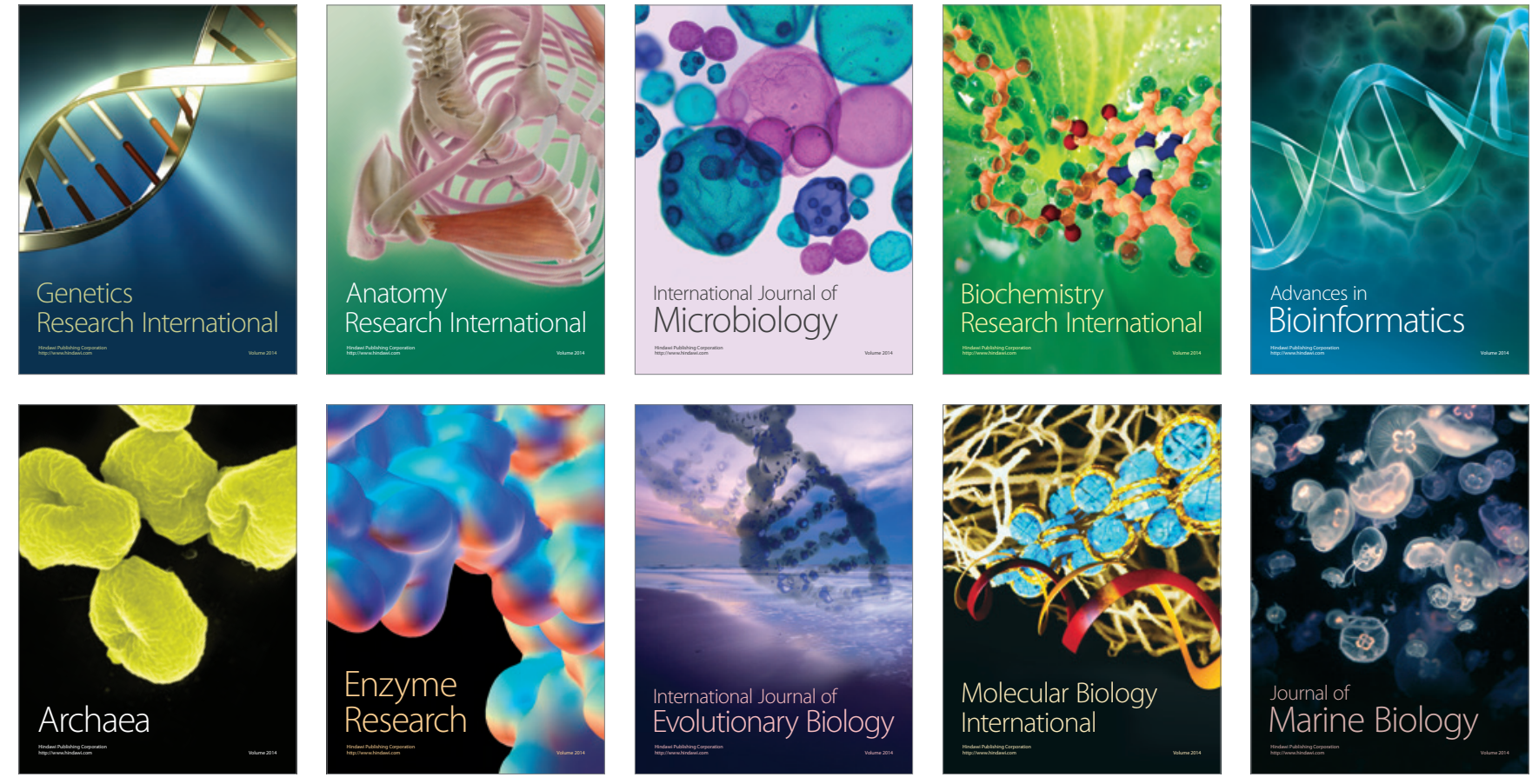